\title{
Finno-Ugric and Turkic Ethnocultural Space Volga Region: The Level of Interaction
}

\author{
Liailia Ihsanovna Mingazova \\ Kazan Federal University, Kazan, Tatarstan, RUSSIA \\ (D) 0000-0001-5116-1419 sc 56436613500 D M-4180-2013 \\ Leila69@inbox.ru
}

\section{Vladimir Ilyich Rogachev}

Doctor of Philological Sciences, Professor, Department of Literature and Methods of Teaching Literature Mordovian State Pedagogical Institute named after M.E. Evsevyev, RUSSIA

(iD) 0000-0001-8021-9114

\begin{abstract}
ARTICLE INFO
Received: 1 July 2019

Accepted: 3 December 2019

Published: 28 December 2019

DOI: https://doi.org/10.29333/ojcmt/6441

ABSTRACT

The study is devoted to consideration of the interaction of the Mordovian and Tatar peoples in wedding ceremonies and folklore. In a comparative analysis of the aspect of the traditional wedding rites and folk poetry Mordovians and Tatars. Interethnic interaction Mordovians and Tatars is a thousand-year history. The impact of the Tatar people on the culture of the Finno-Ugric peoples, including the Mordovian significantly. It is reflected in the material culture: in the home, the cut and the kinds of garments, handicrafts and economic classes, ethnic cuisine. Especially significant penetration processes of cultural elements in the rites and traditions, folklore. Life MordoviansKaratau-ethnic environment of the Volga region, in close contact with neighboring peoples could not but have an impact on their wedding ceremony and folklore. Wedding enriched with new genres and works, artistic and pictorial language and means, becoming one of the unique phenomena of integration and consolidation processes taking place in the culture of the peoples of the Middle region. Go Mordovians-Karataev the Tatar language - evidence of permanent Mordovian and Turkish contacts with a long history. They are also reflected in the wedding poetry, ritual and culture Mordovians core region.

Keywords: folklore, the peoples of the Volga region, the relationship, ritual songs, comparative analysis
\end{abstract}

\section{INTRODUCTION}

Indicative in this wedding ritual. So Mordvinian "Teyteren Pius Kudo" is similar to "peers girlish" existed at the Volga Tatars (Urazmanova, 2001, p. 96).

Youth festivals, games, scene of love and choice of brides were common in the Volga Tatars and Bashkirs. An interesting form of communication used by pre-wedding during national holidays "Jien" conducted by a group of villages in the so-called Djien districts, between the end of spring field work and the beginning of haymaking and harvest (Saidakhmedovna, 2016; Urazmanova, 2001, p. 70). These included the love of young people from different villages, driving round dances - "tugerek uen", various types of dogonyalok - "taklyk uynau". Considered acceptable joint trips boys with the girls they like - "ozyn uen" ("long game"). Singing and dancing were distributed - "zhyrly biyule Copyright ( $\odot 2019$ by OJCMT ISSN: 1986-3497 
uennar", accompanied by ensemble music (Urazmanova, 2001, p. 74-75). After the holidays, sharply increased the number of playable weddings. Aim of present study was to investigate the Finno-Ugric and Turkic ethnocultural space Volga region, with attention to level of interaction.

\section{METHODS}

National holidays of the peoples, the traditions, peculiar features of performance, its mythological foundations and poetic texts are investigated in the works by Urmancheev (2009), Bayazitova (2010), Urazmanova (1984), Zakirova (2011), Mingazova (2016), Sayfulina (2006, p. 117), Akkuzova et al. (2018), Nabiyeva (1989), Ashurbeyli (1982), Xürrəmq1zı (2006), Paşabəyli (2009), Oleari (1985) and others. Despite the rituals, customs, rites having been considerably researched, some of them, for today, continue to be out of researchers' eyeshot (Mingazova, 2014, p. 253).

Different forms of comparative analysis allow to trace the processes of continuity of artistic merits of various national literatures and folklore, typological convergence, to determine the interrelations and influences, which were subsequently concretized in the works by theorists of comparative literature study, Alekseev, Zhirmunsky, Conrad, Neupokoyeva. They have devised the basic abstract theorems of Russian comparative literary criticism (Konrad, 1972; Neupokoyeva, 1976).

\section{RESULTS AND DISCUSSION}

Similarly, youth leisure Bashkirs were organized. For example, during a party - "Kiz kuzleu" arranged dances - "tugerek" verbal contest - "eytesh" (Sultangareeva, 1994, p. 47). Youth revels Volga peoples can not be imagined without folklore. Poetry repertoire "Kiz kuzleu" constituted "Takmak" lyrics, sentences, dialogues, poetic competitions (Sultangareeva, 1994, p. 47). At the same time it was the bride, which assessed the ability to act, sing, dance, and wield sharp buzzword, tastefully dressed. Bashkirs as Mordovians, there was a showdown, both among the young and among the chosen girl and her parents, poetic explanations and verbal competition between girls and boys. Erza and Moksha have arranged autumn-winter visitality girls have relatives living in the neighboring villages, where at parties and merrymaking going on pre-wedding acquaintance youth. Typologically similar in nature and time of the detected visitality the Tatars. At parties guys keep an eye on a bride from neighboring villages and even steal their (custom "chanaga salyp Alyp that kiteler idea") (Urazmanova, 2001, p. 95).

A great place in the premarital period, the girls took the life of the various types and forms of divination to predict the fate and, as it was considered to accelerate the realization of expectations. As Mordovians and the Tatars existed divination on the rings of contraction and wedding. They were called "Nardugan". In the lowered bucket rings and stirred in the dark. Leading randomly took out the ring, and the girls at this time, making a wish, fulfilled love poems - "Takmak" (Urazmanova, 2001, p. 104-105).

Interesting processes in the Volga region took place in areas of dispersed residence of Finno-Ugric and Turkic peoples. This is where you can experience firsthand the internationalization of wedding rituals and folklore, due to the fact that here were made interethnic marriages.

Typologically general points can be traced to the stage premarital rite, when the girls are wondering. During the divination was believed if the chicken. Used when guessing does not make a noise, the in-law will be quiet, if the chicken came across noisy, the inlaw is a contentious [PMA: Perfilova]. Behavior chicken have dispersed Tatars living with 
Mordvinians interpreted as follows: "if the chicken made to the house, taken to drink water, the husband is a drunkard. If, however, began to peck at the grain, then the family will be hospitable" (Urazmanova 2001, p. 106).

In Mordovians existed ceremony bestowing the bride After-Ava ring, in which the bride threw the ring into the water with the words: "Be merciful to me! Give me health, happiness, and many sons and daughters» (Harva, 1952, p. 196). A similar ritual existed among the Tatar-Mishars. On the day of the wedding the young led to the well or the river "Su whirligig kursetu" which brought a gift sous iyase ( "guardian of water"), unleavened bread "kumech" and a silver coin, and then she drew buckets of water, which the participants of the wedding bathed (Mukhamedova, 1972, p. 172). As in Mordovia ceremonial, the Tatars respected traditional magical three times and only the fourth pair of buckets moloduha carried home.

Tatars and Bashkirs as a gift Protecting water was offered a silver coin, while Mordovians - ring. Before water set Bashkir bride had "umilostlivit water spirits and to ensure their invulnerability by throwing into the water the coin with the words" Mine Alma, Moon al" ("Do not touch me, and take here this coin ") or "Sir syrhauymdy dom" ("I will take away sickness and disease") [Sultangareeva, 1994, p. 97).

In Mordovians, Tatars in the second half of the eighteenth century was the custom of parents committed engagement of children at an early age. During Sabantui children (girl and boy) summed together and forced to bite the ears. Similar ceremonies were observed in the Buryat, the Kirgiz (Sultangareeva, 1994, p. 36). On the features of the engagement of children in Mordovians I. Lepyokhin reports the following: "During the national hither swarms (Gathering of people, the holiday - VR) they (the. Parents - VR) changing with each other horns with tobacco, they say "see the good people that we are each other Svatovo ...". If the contract is terminated by the party, could not resist a contract pays a penalty of 6 to 12 rubles "(Lepekhin, 1771, p. 172). He writes about the same well-known popularizer of Mordovian culture K. Miljkovic, who was in the late XVIII - early XIX century. Mordovians in places of residence in the Tambov and Simbirsk (Miljkovic, 1851, number 32). Similar incidents, but the issuance of marriage of minor girls, met in Tatar environment.

The great similarity found in the morning prichetah bride-mordovki. Morning laments were prologue evening. They are found in many nations, particularly in dispersed living with Mordvinians Tatars. Typological unity of their nature is not in doubt. So, early in the morning, at dawn, after the first cocks the bride came out into the yard, and turned to dawn, began to wail:

Ai tan Mycenae, Mycenae tan, whether already come dawn,

Tannyn zaryalary bar Mycenae? Does he have the dawn?

Tannar atkan chakta kychkyryn elyym, At dawn I was crying,

Minnen yazulyrak bar Mycenae? Is there anyone more miserable me?

(Mukhamedova, 1965, p. 191).

Similar in spirit and content to the Mordovian morning lamentations bride in Kasimov Tatars (Mukhamedova, 1965, p. 191).

For morning laments bride Tatar characterized as high poetic style, psychology, stress. In her monologue I felt human drama. Forced to start their lives again, completely in the dark, in someone else's family, the bride acutely and painfully experiencing a situation that is vividly reflected in the works of this genre. 
Bride in tears from the mother's bed and went over to her friends, turning to him with weeping, she lifted them: "Wake up, podruzhenki, time to get up, it's time to lament" tan kuchat (Mukhamedova, 1965, p. 191). "Tang kuchat" - in the language of the Tatars of Mordovia lyambirskih means "make you cry." Morning lamentations bride-Tatar evolved about the same pattern as that of the Mordovians.

In the morning laments Mordovian and Tatar brides there are strong similarities, if not a complete coincidence. To mourning-Tatar bride heard reproaches his father that "he gives her too early, want to get rid of her mother - she is ruthless, his older brother and his wife - that they consider it to be more than a mouth in the family and try more to give married" (Mukhamedova, 1965, p. 191).

\section{SUMMARY}

Particularly strong influence of the Tatar language, wedding ceremonies and folklore manifests itself in the culture Mordovians-Karatau. Differences wedding folklore Mordovians-Karataev from existing Mordovians-Erza and Moksha are as follows. Firstly, verbal-poetic part of the wedding functioned mainly on Mishar dialect of the Tatar language, which could not impose the print on the artistic and visual, linguistic, stylistic means. Secondly, the transition Karatayev the Tatar language has led to the emergence of such new for this group Mordovians poetic genres like "Takmak", typical of Turkic peoples; along with these oral works Mordovians-Karataev no songs about the marriage of children to adult girls, about the kidnapping of brides, not marked texts associated with the ritual of naming. Third, there are differences "in relation" to the works of poetry wedding ceremony. So, despite the presence of morning and evening prichetov, they were not so long. Fourth, there was a difference in the extent and volume of lamentations. The limited use of their wedding in Karatayev binds us to the influence of the local population: the Tatars indigenous region, especially Kazan, prichety received poor development or not marked at all. In Mordovians core region were the dominant genre of wedding poetry. Fifth, for Karatayev peculiar division of the songs on the execution duration (long, short), the place of execution (street, drinking), purpose ( "tui dzhyry" - wedding songs intended guests), whereas Mordovians-Erza and Moksha was graduation by poetic genres (prichety, koril'nye, songs of praise, etc.), the nature of performance (long, short songs), time (morning and evening prichety), as well as the personification of laments (addressed to his father, mother, girlfriend). Sixth, the Mordovians-Erza and Moksha no specific barking dog of the bride, the myth of the celestial supreme arbiter, which bound the hair guy and a girl.

\section{CONCLUSIONS}

Life Mordovians-Karatau-ethnic environment of the Volga region, in close contact with neighboring peoples could not but have an impact on their wedding ceremony and folklore. Wedding enriched with new genres and works, artistic and pictorial language and means, becoming one of the unique phenomena of integration and consolidation processes taking place in the culture of the peoples of the Middle region. Go Mordovians-Karataev the Tatar language - evidence of permanent Mordovian and Turkish contacts with a long history. They are also reflected in the wedding poetry, ritual and culture Mordovians core region. 
Online Journal of Communication and Media Technologies, 2019

\section{ACKNOWLEDGEMENTS}

The work is performed according to the Russian Government Program of Competitive Growth of Kazan Federal University.

\section{REFERENCES}

ACA. (1997). Written by Nadezhda Alexandrovna Perfilova 1913 born. in a. Engalycheva Dubno district of the Republic of Moldova in 1997.

Akkuzova, A., Mankeyev, Z., Akkuzov, A., Kaiyrbekova, U., \& Baiymbetova, R. (2018). Some features of the meaning "literary text" in the pragmalinguistic aspect. Opción, 34(85-2), 20-34.

Field materials author further - PMA. (2004). The conclusion is made on the basis of the analysis on a festive embroidery clothing samples and towels mother LA Gloninoy in with. Mordvinic Karatay Kama-Ustinsky district of the Republic of Tatarstan in 2004.

Harva, U. (1952). Die Religiosen Vorstellungen der Mordwinen. U. Harva. - Helsinki.

Lepekhin, I. (1771). Day notes travel doctor and the Academy of Sciences associate Ivan Lepekhina in various provinces of the Russian state, in 1768 and 1769. Lepekhin. St. Petersburg: Type. when Imperato. Academy of Sciences.

Miljkovic, K. (1851). Topographical description Simbirsk governorship / K. Miljkovic. Simbirsk Provincial Gazette, 31, 32.

Mingazova Liailia, I., GalimullinFoat, G., \& Galimullina Alfiya, F. (2016). The mythological image of shuralen and its reflection in the folklore of Volga-Ural region. Turkish online Journal of Design Art and Communication, 6(Is), 3256-3262.

Mingazova, L. I., Galimullin, F. G., \& Galimullina, A. F. (2014). Folk heroes in the poetry of the people of the Volga and Ural regions. Journal of Language and Literature (Baku, Azerbaijan), 5(4), 252-555. https://doi.org/10.7813/j1l.2014/5-3/42

Mukhamedova, R. G. (1965). Cultural relationship Mordovian and Tatar peoples according Ethnography. RG Mukhamedova. Ethnogenesis Mordovian people. Saransk, 185-194.

Rogachev, V. I. (2004). Wedding Mordovians Volga region: the ritual and folklore (historical-ethnographic and mythological foundations, regional and linguistic aspects). VI Rogachev. Saransk: the muzzle. Publishing House.

Saidakhmedovna, U. D. (2016). UZBEK "MOTAM YOR-YOR" SONGS. UCT Journal of Social Sciences and Humanities Research, 4(4), 17-20.

Sayfulina, F. S., \& Karabulatova, I. S. (2014). European studies of barabin tatar folklore: the role of investigations of the german scientist V.V. Radlov. Life Science Journal, $11(9 \mathrm{~s}), 116-119$.

Sultangareeva, R. A. (1994). Bashkir Wedding-Ritual Folklore. RA Sultangareeva / Ufa Science. Ufa: Ufim. Polygraph.

Urazmanova, R. K. (2001). Rites and celebrations of Urals and Volga Tatars: (The annual cycle of the nineteenth - early twentieth century). RK Urazmanova. Kazan: Publishing House of PIK "Printing House".

Zaragoza, A., \& Çetin, Ç. (2009). Türklerinin Gelenek ve Görenekleri (pp. 11-13). Ankara: Karadeniz Dergisi Yayınları. Nevruz.

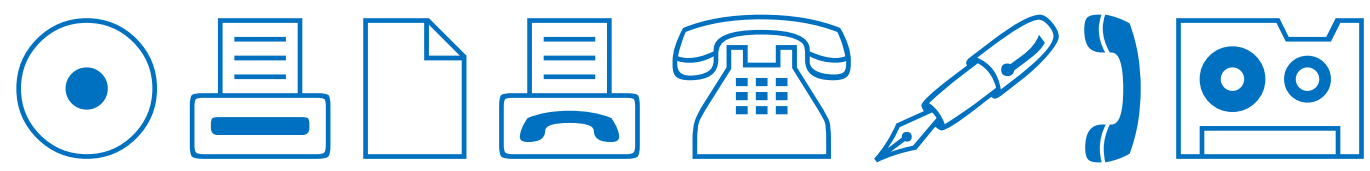

